\title{
ISTR; Democratization, Marketization and the Third Sector: 10. međunarodna konferencija, Siena, Italija, 10 - 13. srpnja 2012.
}

U Italiji, Siena, od 10. do 13. srpnja 2012. održala se međunarodna konferencija ISTR-a (International Society for Third Sector Research). ISTR je najveća međunarodna organizacija koja se bavi istraživanjima u trećem sektoru. Pojam treći sektor je u upotrebu uveo poznati filantrop i poduzetnik David Rockefeller početkom sedamdesetih godina prošloga stoljeća. Treći sektor je složen pojam. Za njega se često kao istoznačnice koriste neprofitni sektor, dobrotvorni sektor, nevladine organizacije ili, danas najčešće, civilno društvo. Treći sektor predmnijeva da osim države i privatnoga biznisa postoji treće područje koje utječe na razvoj. ${ }^{1}$ Razvoj se legitimira otvorenošću i ravnopravnošću svih inicijativa. Riječ je o prostoru u kojem se inicijative i energija pojedinaca može koristiti za javno dobro.

Konferenciju je ugostio i organizacijski potpomogao Università degli Studi di Siena. Ovogodišnja konferencija bila je slavljeničkoga karaktera, obilježavala se 20. godišnjica prve konferencije, koja se na temu Founding of Society održala 1992. godine. Ovogodišnjom konferencijom pod naslovom Democratization, Markretization and the Third Sector slavilo se 20 godina od kada je počeo rad na formiranju globalne zajednice istraživača i drugih zainteresiranih osoba posvećenih stvaranju i promociji znanja, dijalogu o trećem sektoru i njegovu utjecaju na dobrobit čovječanstva, te internacionalnom razvoju.

Tema konferencije dovoljno je široko postavljena kako bi se privukao različit tip zainteresiranih dionika za rasprave o tekućim globalnim promjenama i njihovom utjecaju na treći sektor. Demokratizacija i uloga civilnoga društva u socijalnoj integraciji u zadnje su vrijeme pod povećanom pažnjom, posebice imajući u vidu pokrete mobilizacije na Srednjem istoku i Sjevernoj Africi, te otpor tekućim pokušajima opresije civilnoga društva od strane određenih autoritativnih režima. Novi mediji, društvene mreže i druga tehnološka dostignuća pokazala su da mogu pružiti nove mogućnosti u organiziranju kolektivne akcije i pluralizmu djelovanja civilnoga društva.

Ova 20. međunarodna konferencija u Sieni pružila je mogućnosti za daljnji dijalog o ovim i drugim promjenama u okružju validnosti, refleksivnosti, autentičnosti i kreativnosti.

Konferencija je doista bila globalnoga karaktera. Interdisciplinaran pristup također je važna oznaka ove konferencije. Na njoj su sudjelovali znanstvenici i istraživači iz

1 Bežovan, G. (2008). Socijalna politika i neprofitni sektor, u: Puljiz, V. (Ur.). Socijalna politka Hrvatske. Zagreb: Pravni fakultet. 
područja sociologije, ekonomije, socijalne politike, prava, javne uprave, psihologije, političkih znanosti, teoretičari trećega sektora i civilnoga društva, ali i filozofi i teoretičari novih medija. Velik dio sudionika činili su praktičari koji svoje karijere grade u trećem sektoru. Također, na konferenciji su sudjelovali i dionici iz privatnoga i javnoga sektora, poduzetnici, predstavnici lokalnih, regionalnih i nacionalnih uprava, te manji dio političara. Sudjelovalo je više od 665 osoba iz 68 zemalja sa svih kontinenta u 118 radnih sesija. Jedan dio sesija bio je u obliku panel sesija posvećenih konkretnih istraživačkim projektima i predstavljanju njihovih rezultata. Održano je 475 izlaganja.2 Poseban trud može se vidjeti i u broju volontera uključenih u organizaciju, kao i u činjenici da je pri odabiru izlaganja za konferenciju napravljeno preko 1.500 recenzija pristiglih radova, što pridonosi njezinom značaju i relevantnosti.

Sudionici su bili sa svih kontinenata, te su na konferenciji, između ostalih, održani sastanci Afričke, Azijsko-pacifičke, Latinoameričke i Karipske istraživačke regionalne mreže. Također, mnoge druge organizacije povezane s istraživanjima u trećem sektoru iskoristile su ovu prigodu da naprave radne sastanke sa svojim pripadnicima iz cijeloga svijeta.

Na plenarnom izlaganju konferencije ugledni politički teoretičar John Keane izlagao je na temu After Capitalism, Socialism and Democracy. Retrospektivno iščitavajući klasično djelo Johna Shumpeterea Kapitalizam, socijalizam, demokracija, kroz prizmu razvoja i razmišljanja o trendovima u posljednjih 50 godina pokušao je ustanoviti i predvidjeti buduće trendove i sagledati nove prostore za reotkrivanje civilnoga društva. Posebnu pozornost je usmjerio na empirijsko potvrđivanje mogućnosti civilnoga društva u praćenju i nadgledanju razvoja demokracije.

Konferencija je pokrila cijeli spektar tema koje se tiču civilnoga društva i trećega sektora. Posebno se naglašavao komparativan pristup i vrijednost interdisciplinarnoga znanja. Konferencija je počela s nekoliko tematskih radionica koje su bile zamišljene kao prostor zajedničkoga osvrta istraživača i drugih dionika na razvojni aspekt i buduće izazove organizacija trećega sektora. Na njima se posebno razmotrio utjecaj tekuće ekonomske krize i mogućnosti u novom povezivanju s inicijativama građana. Posebna pozornost, kao što je uvijek običaj na ISTR-ovim konferencijama, posvetila se zemlji domaćinu. Uz izlaganja talijanskih znanstvenika unutar drugih tema plenarna sesija drugoga dana bila je posvećena trenutnom stanju i problemima organizacija talijanskoga civilnog društva.

Gledajući grupno teme najviše izlaganja bilo je povezano s tematskim blokom Civilno društvo, građanstvo i demokracija. Navedena tema uvijek je aktualna za promišljanje o područjima novih razvoja i budućnosti civilnoga sektora i društva u cjelini. Valja naglasiti da se kroz više izlaganja otvoreno sagledavalo sadašnje stanje i mogućnosti civilnoga društva na srednjem istoku i u zemljama pod autoritativnim režimima. U mnogim zemljama treći je sektor tek u nastajanju, a nosi potencijal jed-

\footnotetext{
2 Sažetke izlaganja se može pronaći na: (http://www.istr.org/?SienaAbstracts).
} 
noga od glavnih dionika u promjenama prema demokratizaciji tih društava. Stoga se posebno naglašava njegova otvorenost i ravnopravnost svih vrsta kvalitetnih inicijativa koje se unutar njega pojavljuju. Prostor za raspravu se posvetio smjerovima budućega razvoja civilnoga društva i građanstva, uzimajući u obzir događanja u širem društvenom kontekstu.

Drugi tematski blok po broju izlaganja je bio Socijalno poduzetništvo, socijalno poduzeće i socijalne ekonomija. Velik broj izlaganja i sudionika koji su bili uključeni u rasprave sugerira kako je socijalno poduzetništvo uzelo razvojni zamah, ne samo u organizacijama koje ga prakticiraju, nego i u akademskom području. Riječ je o području koje se još uvijek oblikuje, mijenja i pokušava precizno definirati, stoga je ova konferencija poslužila i kao okvir za promišljanje o poteškoćama i izazovima koje prati njegov razvoj. Socijalno poduzetništvo stavlja ekonomski imperativ u trećem sektoru na njihov društveni i politički kontekst. Svaka analiza njihovih perspektiva oživljava staru plemenitu tradiciju u političkoj ekonomiji, vjerovanje da ekonomska aktivnost mora koristiti cijeloj zajednici. U svakom slučaju, brojna izlaganja na tu temu, koja smo koliko su nam mogućnosti dopuštale i posjetili, ukazuju na razvojni potencijal navedenoga područja. Mnogi gaje nade kako bi se upravo socijalno poduzetništvo i socijalna ekonomija mogli uspostaviti kao relevantan akter na razmeđi ekonomije i civilnoga djelovanja usmjerenoga na rješavanje problema u društvu i etabliranja novih vrijednosti.

Postojao je još značajan broj tematskih blokova koji su bili zastupljeni pokrivajući gotovo sve tematske aspekte zastupljene u trećem sektoru. Izdvojit ćemo još tri s najviše izlaganja - Evaluacija, legitimacija, odgovornost $i$ utjecaj, naziv je jednoga od njih. Brojna su izlaganja posvećena pitanju pozicioniranja organizacija trećega sektora u društvu. Raspravljala su se pitanja kako i zbog čega su oni legitimni akteri, te kako ih evaluirati i mjeriti im utjecaj da bi se osigurala održivost, vidljivost njihove koristi za zajednice i osobe, te poticala kvaliteta njihovoga djelovanja.

Management i organizacijska praksa također je bio tematski blok s velikim brojem izlaganja. Izlagani i raspravljani su trendovi u upravljanjima organizacija trećega sektora, sagledavana različita viđenja načina kako organizacije trećega sektora mogu biti učinkovitije u svim fazama svoga organizacijskog procesa, i koji je odnos managementa i organizacijske prakse u okviru širih društvenih trendova.

Filantropija se isto tako izdvajala kao tematski blok, po broju izlaganja. U izlaganjima su bile predstavljene različite forme i oblici filantropije, te djelovanja zaklada u različitim dijelovima svijeta. Identificiralo se stanje i specifičnosti filantropije danas. Razmatrani su i izazovi i prepreke filantropskom djelovanju i načini njihovoga prevladavanja, ocrtavajući tako ovo područje s golemim potencijalom za poboljšavanje ljudskih života. Ostali tematski blokovi unutar kojih su održavana izlaganja bili su sljedeći: Nastajuća područja teorije i prakse; Rod; Vladavina i vodstvo; Pravda i razvoj; Javne politike, politika i odnosi; Istraživačke $i$ nastavne paradigme, metodologija i praksa, te Volontiranje i volonterstvo. 
Konferencija Democratization, Marketization and Third Sector okupila je velik broj istraživača, ali i poduzetnika, javnih službenika i drugih zainteresiranim dionika u trećem sektoru iz cijeloga svijeta. Također, pružila je priliku da se u otvorenom okruženju raspravi i o razvoju istraživanja u njemu. Predstavljala je platformu za seciranje stanja trećega sektora i njegovih dosega na svim kontinentima. Omogućila je širu sliku i pružila interdisciplinarne uvide u trendove, razvojne mogućnosti, ali i probleme i prepreke s kojima se organizacije u trećem sektoru susreću, i u tom je vidu možemo smatrati itekako uspjelom.

Danijel Baturina

Studijski centar socijalnog rada; Pravni fakultet Zagreb 